Continuity and Change - The Planning and Management of Long

Distance Walking Routes in Scotland

Stephen Morrow

Senior Lecturer

Department of Sports Studies

University of Stirling

Stirling FK9 4LA

01786466495

s.h.morrow@stir.ac.uk 


\section{Continuity and Change - The Planning and Management of Long Distance Walking Routes in Scotland}

\section{ABSTRACT}

In recent years a number of changes have taken place in Scotland in respect of issues of land management, access and the natural environment. These include the creation of Scotland's first National Parks in 2002 and the introduction of the Land Reform (Scotland) Act 2003, which has enshrined in legislation the principle of responsible access in the countryside. The aim of this study was to consider the implications of these changes for a specific type of recreational land use in Scotland, Long Distance (Walking) Routes (LDRs). Using semi-structured interviews with representatives of a number of agencies and with other individuals closely involved with LDRs, the research considered the extent to which these changes have or may alter the rationale for the provision of LDRs, their funding and their management. The research indicates a need and a willingness to build on existing stakeholder approaches to management with a view to engaging a broader range of communities of interest. The main challenge for those involved with LDRs is how to fund future development of these routes. One aim of a more participatory stakeholder management approach is to help route managers to use public funds to lever funds from other sources. 
But only mature industrial societies self-consciously create primitive footpaths of 400 or more kilometres in length whose sole function is to produce the opportunity to walk the distance of the trail. Only a population that had 'nothing to do' would expend considerable resources of capital, labour, and time on a leisure activity that populations in other political economies would consider work. (Burch, 1979, p.9).

The West Highland Way is getting out, it's getting into the Highlands, it's fantastic landscapes, it's a challenge, it is getting from the start to the finish, the physical challenge. (Interview with Loch Lomond and Trossachs National Park, July 2004).

\section{INTRODUCTION}

Like the United States where early long distance routes like the Oregon Trail or the Santa Fe Trail were associated with emigration and settlers rather than with leisure, long distance walking routes in Scotland came into existence not to showcase the beauty of the Highland landscape, but out of economic and social necessity. For centuries vast tracts of wild land have been covered by a complex network of drove roads, military roads, Pictish roads, coffin roads, whisky roads and stalking paths, and were often the sole means of communication between one community and another (Storer, 1991). But while trails were developed for recreational purposes in other countries in the late $19^{\text {th }}$ and early $20^{\text {th }}$ Century - e.g. the Appalachian Way was established in 1925, becoming the first designated national scenic trail in 1968 - officially 
designated national trails or Long Distance Routes (LDRs) in England and Scotland have a much shorter history. The Pennine Way, the first National Trail in England, was opened in 1965, while the first LDR in Scotland, the West Highland Way was not opened until 1980. Since then, three other LDRs have been established in Scotland - the Southern Upland Way, the Speyside Way and most recently, the Great Glen Way, officially opened in April 2002 (see Figure 1). Many of the early trails like the Appalachian Way and the Pennine Way were the result of individual vision and voluntary effort (Rubin, 2000; Mattingly, 2005). Interestingly, these influences remain relevant as evidenced in the setting up of unofficial long distance routes in Scotland like the Isle of Arran Coastalway in the last few years (Spotlight, 2002).

Figure 1 goes here

\section{PLANNING AND MANAGEMENT}

Scottish Natural Heritage (SNH), the government funded body responsible for the conservation and enhancement of Scotland's wildlife, habitats and landscapes, is responsible for leading the preparation of the proposal for an official LDR and forwarding this to the Scottish Executive for approval by the First Minister. Once approved, the responsibility for the implementation and ongoing management and maintenance transfers to the managing authority (the local authority and the National Park authority as appropriate) through which the LDR passes, with routes being managed on a day to day basis by route managers and/or rangers. Other bodies are also involved in the management of the routes: for 
example, the Forestry Commission and the British Waterways Board are represented on the Great Glen Way Management Group.

Different mechanisms for developing, managing and funding LDRs exist in different countries. For example, in the United States non-profit trail organisations work directly with Federal agencies like the National Park Service and the Bureau of Land Management to sustain particular trails, under an umbrella organisation, the Partnership for the National Trails, which acts to further the protection, completion and stewardship of the entire National Trails Systems and to facilitate interaction and cooperation among the various private groups and government agencies involved with the national trails (Partnership for National Trails, 2005). The system in England and Wales is similar to that in Scotland, with the Countryside Agency and the Countryside Council for Wales being the comparable bodies to $\mathrm{SNH}$ with the power to recommend to the Secretary of State for Environment, Food and Rural Affairs that a new trail be designated. Each Trail in England and Wales has a National Trail Officer who is responsible for overseeing its management and maintenance to nationally agreed standards. Much of the maintenance work being carried out by the local Highway Authority. Funding for National Trails is provided by national government through the Countryside Agency and the Countryside Council for Wales and also by local highway authorities and other funding partners.

An in-depth review of the policy framework within which LDRs should be developed, managed and funded was carried out by SNH in the mid 1990s. At that time it concluded that there was no need for radical change in the way in 
which the routes were managed (SNH, 1997, Foreword). Elsewhere the Countryside Agency has been considering setting up a National Trails Trust to oversee management of the National Trails network in England and Wales and to improve the funding thereof (The Countryside Agency, 2003), although at the present time the idea has been put on hold (correspondence with The Countryside Agency, August 2005). Trusts have been set up in other countries to manage long distance trails - for example, the Te Araroa Trust which manages the walking trail linking the northern and southern tips of New Zealand (Te Araroa, 2005).

Since the 1997 review a number of changes relevant to broader debate on land management, access and the natural environment have taken place in Scotland. These include the creation of Scotland's first National Parks - The Loch Lomond and Trossachs National Park officially opened in July 2002, followed in 2003 by the Cairngorms National Park - and the introduction of the Land Reform (Scotland) Act 2003, which has enshrined in legislation the principle of responsible access in the countryside. In contrast to England and Wales where access to the countryside has always been a contested area, forcing governments to introduce legislation to give people greater access to the countryside (most recently the Countryside and Rights of Way Act 2000), in Scotland there has always been considerable de facto access to the countryside. Despite this by the late 1990s it was increasingly recognized that change was needed, in part because reliance on the voluntary principle achieved inconsistent results and because visitors and tourists needed clearer access to Scotland's outdoors (Scottish Outdoor Access Code, 2005). While comparable, there are significant differences between the legislation 
introduced in England and Wales and that in Scotland, most notably that the English and Welsh access rights apply specifically to areas which are to be mapped (comprising mountain, moor, heath, down and registered common land), whereas all land in Scotland is covered, whatever its ownership.

Clearly the changes that have taken place in Scotland have the potential markedly to alter the landscape within which LDRs are located. In addition, in recent years a number of unofficial long distance routes have also been developed including the Isle of Arran Coastalway, the Rob Roy Way and the Fife Coastal Path, developments which have altered the landscape of path provision in the country.

\section{RESEARCH AIM AND APPROACH}

The aim of this project was to consider the implications for LDRs in Scotland of developments that have taken place in respect of issues of land management, access and the natural environment. The theoretical underpinning of the research was the role of stakeholder involvement in the provision, development and management of long distance routes. In particular the project offers an opportunity to explore stakeholder collaboration at a time of substantial change.

More specifically the project aimed to consider the extent to which changes in land management, access and the natural environment have or may alter: 
1. the rationale for the provision of LDRs;

2. the funding of LDRs; and

3. the management of LDRs.

This approach involved conducting semi-structured interviews with representatives of a number of agencies and with other individuals closely engaged with long distance routes (both official LDRs and other routes) and recreational walking in Scotland, either in terms of the management, promotion or creation of these routes. While the study was concerned with long distance routes in Scotland as a whole, in the selection of interviewees particular emphasis was given two routes: first, the longest established official LDR, the West Highland Way, and second, the relatively new Isle of Arran Coastalway, established by local enthusiasts and officially opened in March 2003.

Interviews were conducted with representatives of $\mathrm{SNH}$, Highland Council, the Loch Lomond and Trossachs National Park, the West Highland Way Ranger Service, Lochaber Enterprise (the local economic development agency in Fort William), visitscotland (Scotland's national tourism board), the Highlands of Scotland Tourist Board, Ayrshire and Arran Tourist Board and Paths for All (the agency established by SNH to create local path networks throughout Scotland for the enjoyment of local people and visitors); and with Dick Sim, a key figure in the setting up of the Isle of Arran Coastalway. 


\section{THE RATIONALE FOR LDRs}

In its 1997 review paper, SNH identified the following justifications for LDRs in Scotland (SNH, 1997, para. 2.15):

- the need to improve access for people to enjoy the countryside;

- to provide an experience of the natural heritage;

- to provide well-managed and assured access opportunities;

- to widen access and opportunities for people to enjoy the countryside;

- to bring locally significant economic benefits to rural communities through which the routes pass;

- to help market areas for tourism.

Different bodies involved with LDRs place different emphasis on the benefits identified above. While SNH clearly has a national heritage role 'it must also have regard to socio-economic needs, the interests of owners, occupiers and communities, and ensure that its activities are conducted in a sustainable manner' (SNH, 1997, para. 2.15). The first reason why local authorities are involved is quite simply because under the Countryside Scotland Act they are given the legal responsibility to manage the routes. However, the wider social and economic benefits are not lost on councils. For example, with regard to the most recent LDR to be established in Scotland, the Great Glen Way, Highland Council Long Distance Routes Manager observed that 
we jumped at [establishing the Great Glen Way] because we feel ... it's a very useful thing to be involved in the long distance routes. ... I think politically it's a very good thing to have in the area and certainly our politicians are very supportive of our long distance routes ... both [the West Highland Way and the Great Glen Way] have been great for Fort William because people come to stay the night in Fort William before they start walking the Great Glen Way [or when they finish the WHW]. (Interview, June 2004).

The growing popularity of recreational walking in Scotland is well documented (SNH, 2004) as is its economic benefit (Higgins, 2000). A report into the economic impact of the West Highland Way found that approximately 50,000 people use the route annually, bringing £3.5m into the economy (SNH, 1998). Furthermore, research evidence suggests that for many people there is a shift away from organized group sports to more individualised forms of active recreation, with walking and cycling trails being an increasingly significant resource for sporting activity in many countries (Ravenscroft, 2004).

One focus of the project is to examine the putative benefits or justifications identified by SNH within the broader changes in land management, access and the natural environment. Perhaps the most notable impact will be the implications of the Land Reform (Scotland) Act 2003 given that the new legislation provides a statutory right of responsible access to land for recreation purposes (Part 1, Chapter 1). Ostensibly, therefore, walkers no longer require a LDR to permit them assured access. As responsible access 
has only been provided since February 2005 when the Scottish Outdoor Access Code was published, to date there is no observable impact. Looking forward, however, the legislation will affect routes where management arrangements exist with landowners in that there is no longer a requirement to secure access for the routes. Agreements will still be necessary, though, for other issues like taking machinery onto private land, maintenance etc. (Interview with SNH, November 2004).

Perhaps of greater interest is how walkers will respond to changed access rights. While nothing in the legislation alters access rights on LDRs given that secure access has always been provided by these routes anyway, nevertheless the legislation may affect walker behaviour. Some have been critical of LDRs, for example likening walkers to package holiday tourists blinded to other walking options (Edensor, 2000). In this study it has been suggested that as confidence grows, some walkers may respond to the changed access framework in Scotland by progressing from LDRs to other areas of the outdoor environment, safe in the knowledge of secured access (interviews with SNH, November 2004; Highlands of Scotland Tourist Board, June 2004). Another possibility is that if the Land Reform (Scotland) Act is successful in changing lifestyles, and helps achieve key public policy objectives in areas like health, sustainable transport, social inclusion and rural regeneration, then it may actually be beneficial for LDRs, giving people confidence to undertake walks more remote from their homes, including LDRs or sections thereof (interview with Highlands of Scotland Tourist Board, June 2004). Notwithstanding these and other possible implications for LDRs, SNH 
is not in any way concerned about the need for these routes per se in the light of the new legislation (interview with SNH, November 2004).

More generally, it is important to recognise that access is only one barrier to participation, and furthermore that it is a particular type of barrier; essentially a structural barrier largely external to the individual. Drawing on interviews of users of non-motorized cycle and walking routes, Ravenscroft (2004) argues that constraints are more often articulated in intrapersonal (e.g. reference group attitudes, perceived skill levels) or interpersonal (e.g. availability of an activity partner) terms rather than in structural terms. While policy prescriptions have previously tended to focus on structural barriers, some recent evidence from the Paths for All and Paths to Health projects suggests a willingness to develop outdoor recreation policy which addresses structural and personal barriers:

... [there are] two halves of the organisation at the moment ... one [Paths for All] is looking at the infrastructure, the access strategies, the support for access officers ... The Paths to Health project is very much about getting people out and walking. ... [they have] volunteer walk leaders and there's over 700 of them now across Scotland, ... running walks two, three, four times a week, depending on where they are. They advertise them locally and people are coming along. ... a lot of it is about the social side. It's people getting the confidence to come along in the first place and then finding that there are lots of other people just like them and there's 
friendships getting up, there's people being able to take on things that they never thought they could. (Interview with Paths for All, June 2004).

\section{STAKEHOLDER MANAGEMENT}

Stakeholder theory is well developed in the business management literature. It pertains in particular to the social responsibility and responsiveness of business organisations; extending the scope of managerial attention beyond the providers of financial capital (shareholders) to include other groups or individuals who can affect or are affected by the achievement of the firm's objectives, such as employees, local community, government and customers (see, for example, Ansoff, 1965; Donaldson and Preston, 1995; Freeman, 1984). But while it is most commonly discussed in the context of business organisations, its applicability is also considered in a wider range of other settings as diverse as the United Nations (Mikalsen and Jentoft, 2001), the public sector (Scholes, 2001), cultural landscapes (Selman, 2004), football clubs (Morrow, 2003), heritage management (Aas et al. 2005), inter-collegiate athletics (Covell, 2004) and fisheries management (Mikalsen and Jentoft, 2001).

While normal practice has been to assign the management of landscapes and wildlife resources to a specific agency, the importance of involving and engaging stakeholders (communities of interest, communities of place) in landscape management has been increasingly acknowledged (BorriniiFeyerabend, 1999). Selman $(2004,368)$ suggests that stakeholders typically: 
- are aware of their interests in managing the area, even though they may not be aware of all its management issues and problems;

- possess specific capabilities (knowledge, skills) and/or comparative advantage (proximity, custom, mandate) for such management; and

- are usually willing to invest specific resources (time, money, political authority) in such management.

In common with other countries like England and the United States, recent management of LDRs in Scotland has rested upon a stakeholder approach. Cooperation and partnership exists amongst a variety of public and private actors, each with differing roles and responsibilities vis-à-vis funding and management of the routes. This structure is akin to some descriptions of modern firms, represented not as top-down hierarchies but coalitions of interest groups with conflicting demands and expectations (Cyert and March, 1963).

Historically the key stakeholders have been the government-funded, nondepartmental body, $\mathrm{SNH}$ (indirectly accountable to the public in the form of taxpayers), the relevant councils (funded by and accountable to their local electorate) and more recently the National Park authorities (funded by the government and thus indirectly accountable to the public in the form of taxpayers). In addition other stakeholders such as local tourist boards, local enterprise companies and government-funded, non-departmental bodies like the Forestry Commission can be involved in the management and development of routes on either an ongoing basis or an ad-hoc basis. 
We've tended to be a kind of catalyst at the front end [of a project] in terms of the path creation and working with other agencies in the development of it and opportunities [arising out of it]. But ... when something new comes along we're obviously able to work with other agencies in partnership ... (Interview with Lochaber Enterprise, June 2004)

The over-riding impression is one of a partnership relationship that works because of the commitment and competence and of the individuals involved. A strength of stakeholder approaches is their inclusivity; their recognition of different communities of interest, public and otherwise. The stakeholder model of management of LDRs is certainly viewed as appropriate by $\mathrm{SNH}$ :

... we would be hard pressed to come up with a better model. This structure enables us to tap into key partner organisations and individuals. It is about stakeholder engagement; about communities of interest ... (Interview with SNH, November 2004).

That said there is also recognition of a need to reach out to wider publics or communities of interest. One illustration of this arises from the appointment of a Development Manager for the West Highland Way. One role of this position is to advance the Development and Management Programme (DMP) - the primary planning and management document for each long distance route through a more inclusive consultation process. 
The idea is to engage with interest groups and spin off businesses like bag carriers, with a view to finding out from them their views on things like how they think the route should be developed? What is good and bad about the route? It is about feedback and two-way communication with communities of interest. (Interview with SNH, November 2004).

The West Highland Way Development Manager's role will be to liaise with the partners, businesses, land managers and communities along the whole of the 95-mile route from Milngavie to Fort William. Speaking about her new role, Gill [Cox] said, "This is an amazing opportunity to make contact with the communities, land managers and visitors along the route." (A' Phairc, 2004).

\section{FUNDING}

Of course, the adoption of a stakeholder management approach does not equate to consensus and it is clear from the interviews conducted that conflicts surround the provision, management and particularly funding of LDRs at this time. One example relates to the objectives of LDRs, in particular the status of LDRs and, more pertinently, whether the funding approach should be consistent with the designation. There is evidence of a consensus among the various stakeholders that designated long-distance routes have national status. For example: 
SNH's view is that a national role and overview is important as these routes benefit from having national status. (SNH, 1997, para. 3.15).

We've taken the view in Highland Council that long distance routes are the equivalent of trunk roads for walkers ... they're strategic, they're national ... (Interview with Highland Council, June 2004)

... [the West Highland Way is] a flagship for Scotland ... it's a national route ... [it] needs to be recognised, perhaps more fully, that it is a national asset. (Interview with Loch Lomond and Trossachs National Park, July 2004).

Contention arises, however, on whether or not this status is then reflected in the funding of routes. Two particular concerns are expressed by Highland Council: first, that funding of national routes is becoming increasingly dependent on local authorities; and second, that the funding it receives from $\mathrm{SNH}$ in respect of LDRs is locally distributed, rather than nationally (interview with Highland Council, June 2004). What this means is that nominated SNH area offices are designated as lead offices for particular LDRs and hence approval of the DMP and subsequent agreement of funding is the responsibility of that office.

The regional approach adopted by $\mathrm{SNH}$ reflects its organisational and operational structure. Notwithstanding that each local area has a specific responsibility to manage its budget, 'according to SNH procedures and protocols' (SNH, 2005), it is difficult to avoid the conclusion that there is a risk 
of inconsistency and dis-functionality in decision making and funding when the resource concerned is a national resource.

The failure to adopt a national approach to funding seems at odds with the portrayal of LDRs as national routes and also the national approach adopted in respect of other aspects of their management. For example, the decision to set up a National LDR forum, made up of representatives of all Scottish LDRs, was taken in part to facilitate the development of nationally agreed standards for the routes (in terms of things like quality, maintenance, signage etc.) and to improve stakeholder collaboration. More generally, the conflict over the lack of a national approach to funding demonstrates that stakeholder collaboration in itself does not overcome imbalance among the stakeholders in terms of the distribution of power and resource flows (Aas et al. 2005; Reed, 1997). Conflict is almost inevitable where the LDR management group has to bid for central funds and where any deficiency is picked up by one of the other stakeholders.

Different stakeholders will have different motivations for wishing to be involved in something like the planning and management of a LDR. While for some the motivation will be functional (for example, seeking to gain grants), for others it may be interactive (seeking to take a role in shaping decisions) (Selman, 2004). In a study of eco-stewardship partnerships within the Adirondack Park, for example, Michaels et al. (1999) distinguished between capacity-driven participants who use partnerships to compensate for budget shortfalls and commitment-driven participants who use partnerships for activities feasible only through collaboration. The issue of stakeholder motivation is illustrated 
by debate over the objective of the routes and the extent to which the economic benefits follow the funding. Reflecting budget pressure, Highland Council's perspective is largely inputs focused; concentrating on what is sees as its increased share of costs while arguing that it receives little by way of direct benefit. SNH takes a broader perspective, widening the discussion to include outputs such as economic benefits and stakeholder beneficiaries. It argues that councils should bear an increasing burden of the costs as these facilities generate local benefits while its own contribution should be restricted to the natural heritage aspects thereof.

Although Councils have continuing constraints on their expenditure, this is also the case for $\mathrm{SNH}$. SNH, therefore, must move away from offering grants of up to $100 \%$ for facilities that generate significant local economic benefits and substantial local use. (SNH, 1997, 5.1).

... [there is little] commercial incentive to local authorities to invest in tourism as we don't get any payback for it. The commercial operators pay commercial rates [local business taxation] but commercial rates go to the Scottish Exchequer, not to the local authority ... at the end of the day, the people who benefit economically from long distance routes aren't the local authorities who look after the places, it's the businesses on the way ... [yet we are being told by $\mathrm{SNH}$ ] 'well, you're getting this economic benefit so you should be able to get the funding from somewhere else to help you to run this route and the money we're giving you is for the natural heritage element of it'. (Interview with Highland Council, June 2004). 
Although one can see some merit in each side's case, both arguments are partial. While the council is correct in noting that business rates do not go directly to the local authority but rather to the Treasury, it is also the case that the yield collected from non-domestic rates is pooled nationally and then redistributed amongst local authorities on a per capita basis for local spending on things like education, social services etc. (Scottish Parliament Information Centre, 1999). Furthermore it is disingenuous to equate local benefit with direct revenue received, a point noted by SNH and others:

I do not accept the argument that councils pay but receive little back. Inevitably the local area receives benefits. Economic spin offs are enjoyed locally - bunk houses, camp sites, shops etc. .... The routes often go through fragile areas. In fact they help sustain some peripheral communities - some 30,000 people walk the Great Glen Way annually, passing through some very fragile communities. (Interview with $\mathrm{SNH}$, November 2004)

... I would say [the local authorities are] being a bit narrow minded if they think there's nothing in [long distance routes] for them. The local authorities have an element of economic development in their remit. (Interview with Loch Lomond and Trossachs National Park, July 2004).

That said, SNH's position can also be challenged in terms of its prioritising national heritage funding: 
if $\mathrm{SNH}$ [is] now saying that [it] doesn't see [itself] as having a role where these routes are not about natural heritage but [instead] about economic development, I think I will be questioning their need to extend the Speyside Way for instance from Aviemore to Newtonmore. ... There are no natural heritage benefits that I can see in extending that. The rationale I think for extending that route is purely economic. So if they're now saying to us that they're not going to support elements of the operation of running the Great Glen Way because it's economic, then ... you ask the question why are they prepared to fund and presumably run and operate ... the extension of Speyside Way without any natural heritage benefits. (Interview with Highland Council, June 2004).

In any event, the extent of SNH's remit extends beyond natural heritage issues. One of the themes underpinning its corporate strategy is 'promoting sustainable use ... using the natural heritage in a way which respects its longterm value while delivering economic benefit' (SNH, 2003, 5). This explicit mention of delivering economic benefit suggests that restricting its focus to a narrow interpretation of natural heritage is not appropriate. One interpretation of SNH's adoption of a narrow definition is that it is simply a means of helping it to cope with its own budgetary constraints.

We're certainly having difficulties just now with the area offices funding the Great Glen Way. They would appear to have budgetary pressures and they're now saying that to us that ... they're not prepared to fund [the Great Glen Way DMP] to the levels that we bid for, on the basis that there 
is an economic development spin-off associated with it. But they seem to have lost sight of the fact that SNH has not only got a national heritage remit but it has also got an economic development remit within its role. (Interview with Highland Council, June 2004).

Further challenges lie ahead which may exacerbate these financial and budget conflicts. Most obvious is the requirement of the Land Reform (Scotland) Act for local authorities to provide Core Path Networks. Under the Act local authorities have three years from the date of responsible access going live (February 2005) to plan and consult about core path networks in their area. While it is possible that some parts of existing LDRs may be designated as core paths, most informed opinion suggests that core paths and LDRs will be catering for quite different market places and hence any cross over will be limited. However given the budget constraints faced by the councils, one risk is that the prioritisation of funding for core paths may have implications for LDR funding, notwithstanding that councils fund only $25 \%$ of the cost of LDRs.

What is required at this juncture is for those involved with LDRs in Scotland is to build on and develop existing forms of partnership or stakeholder management with a view to ensuring that the routes remain appropriately funded and managed in the future so that they continue to play a major role in outdoor recreation in Scotland. The emphasis needs to be on the collective benefits of stakeholder collaboration. One example of how this may be achieved in practice concerns the Development and Management Programme 
(DMP) prepared for each route by the Managing Authority. DMPs set out the managing authorities' aspirations and strategy for their route as well as details on things like budgets. Ultimately SNH has to approve the DMP for each LDR and agree the funding. Moreover, through its involvement on the steering group it also has an opportunity to influence the direction and content of the DMP.

Historically, the DMP was seen as little more than a bidding document, largely irrelevant to the route management process. Recently the emphasis has switched to making the document central to route management. For example, at the Great Glen Way, the DMP is now seen as a rolling document. While it is still fundamentally reviewed every three years, it is appraised annually. The objective it to make the DMP a dynamic managerial or development took rather than a static bidding document (interview with SNH, November 2004). This change is potentially beneficial for the managing authorities and for other communities of interest; providing a more coherent framework for discussion and decision making. It is also potentially beneficial from a funding perspective as it provides route managers with a programme which provides them with a basis for negotiating for additional local funding. In this regard the introduction of a standard user survey to be used on each of the routes with a view to improving the knowledge base of each of route managers on things like walker spend, walker motivations, economic spin off possibilities etc. should also encourage forward thinking. In the language of business understanding your customers is a pre-requisite to enabling you to manage a particular resource; in ensuring that it achieves its objectives. Within the multi- 
stakeholder model outlined for LDRs in Scotland, communication is very important, and the availability of good quality information of this kind will provide route managers with an opportunity to share that knowledge not only with different recognised communities of interest (for example, in discussions with tourist agencies about promotion of the routes), but also beyond (in discussions, say, with the Scottish Executive about possible health related benefits of LDRs).

Knowledge gained from the surveys will inform the DMP, particularly in the difficult areas of funding or revenue generation. As in other countries like England (see Countryside Agency, 2003) and the United States, the importance of broadening the funding base of LDRs has been recognised. In its 1997 policy paper SNH noted that it 'will work with managing authorities to identify the potential for raising additional funds through sponsorship, merchandising and completion certificates' (SNH, 1997, 5.6), an idea that has found favour with some other stakeholders:

but I think we are now at the stage certainly with ... [the West Highland Way] ... possibly even the Great Glen Way in the not so distant future ... that they might be able to become more self sustaining than they are. We are probably quite slow in Scotland to catch on to ... branding, intellectual property rights [based upon the routes].... the routes may be able to say 'we have an asset that's worth money' and start franchising out certain things like the production of t-shirts. They might start selling more merchandising themselves ... raising income through these sort of 
activities ... none of the routes could be entirely self-financing $\ldots$ but as time goes on and hopefully numbers of people using the routes increases there may be ways of bringing in income rather than relying solely on grants or whatever ... (Interview with Highlands of Scotland Tourist Board, June 2004).

The benefit of incremental income of this sort has also been acknowledged beyond the LDRs. For example, a small range of Coastalway merchandising polo short, sweatshirts - is available on the Island of Arran (interview with Isle of Arran Tourist Board, August 2004).

Information from the evaluation exercises, as well as information from other user sources, such as the online questionnaires available on the Great Glen Way website, will be helpful in appraising the feasibility and financial attractiveness of things like spin offs and branding. But there remains a broader question of whether this should be the way forward for the routes. Certainly not all stakeholders are convinced of the merits of these types of initiatives:

it [has been] suggested to us that in order to provide a sustainable operating budget for that route, we should try and seek external funding or sponsorship of this long distance route. I think quite frankly that is a waste of time and effort on our part. Our staff are there to manage the route, they're not there to go out and secure funding for its continued sustainable operation. (Interview with Highland Council, June 2004). 
Attractive though fund raising schemes may be at first sight, any such initiatives require to be critically evaluated. An important question for local authorities (and other stakeholders) is whether the arrangements satisfy best value criteria. Local authorities are statutorily required to make arrangements to secure continuous improvement in performance (while maintaining an appropriate balance between quality and cost); and in making those arrangements and securing that balance, to have regard to economy, efficiency, effectiveness (value for money) (Local Government in Scotland Act 2003). Thus these initiatives would require to be carefully assessed, both as to their revenue generation possibilities and also in terms of financial control, i.e. the ability and/or willingness of the local authority to ensure that any revenues generated are ring-fenced for LDRs.

The increased involvement of National Parks with regard to two of the LDRs (West Highland Way and Speyside Way) should also be beneficial in the development of improved DMPs, raising the standards of management and governance of recreational land in Scotland. This need not be interpreted as a criticism of other bodies presently involved but rather a reflection that is precisely the type of engagement for which National Parks were created.

I mean, as far as local authorities go, they've got such a wide remit of responsibilities that [LDRs] probably [don't] feature that high. In a National Park, of course it does, because that's what we're about. It's ... well up the agenda because we're not having to think about how to pay for 
schools and social workers and all the rest of it. (Interview with Loch Lomond and Trossachs National Park, July 2004).

National parks [are] an opportunity to raise standards ... [they] should be examples of best practice. [Interview with visitscotland, August 2004]

Nevertheless there remains a need to build on the existing stakeholder management model, seeking to make it more inclusive by widening the communities of interest, but also making it more participatory. In this regard, Selman (2004) provides an excellent summary of examples of participatory landscape management from throughout the world which may inform those involved with LDRs. It is clear that on most LDRs opportunities exist for more active involvement by some of the currently recognised stakeholders, for example, tourist agencies and enterprise agencies, while broadening the communities of interest to encourage the involvement of local communities and users among others may also be beneficial. As noted in the introduction, long distance routes have a long history as public resources, being used for many years for commerce, droving, travel and pilgrimage. While some of these routes were formalised by their designation as LDRs, they still retain their status as public recreational resources. More generally, the Land Reform (Scotland) Act has strengthened the notion of land (or more accurately recreational usage or access to land) as being a public resource. Consequently institutional arrangements for management of LDRs should take the public interest into account. A conclusion of a study into the management of another public resource, fish, was that stakeholder 
management added both political influence and normative credibility to the argument that management institutions needed to be developed where multiple and public interests could be represented in decision-making (Mikalsen and Jentoft, 2001).

One aim of this participatory stakeholder management approach is functional. Active involvement of different communities of interest may allow route managers to use public funds to lever funds from elsewhere. The desire to increase the gearing of Countryside Agency funding by levering new money including private sector money, was one of the motivations behind the idea of setting up a National Trails Trust to promote and enhance National Trails in England (The Countryside Agency, 2001). That said the idea has now been put on hold reflecting concerns that simply setting up a trust was unlikely in itself to bring about an increase in financial support from individuals or the private sector, but would certainly provide a further layer of bureaucracy in the management process (correspondence with The Countryside Agency, 2005).

Broadening and engaging with the communities of interest may also make it easier to emphasise wider socio-economic objectives related to the LDRs. Further, it may also encourage more ground up initiatives. For example, evidence from the Ohio and Erie Canalway in the United States indicates that local groups which have been engaged in aspects of the planning and management of cultural landscapes have taken on tasks like seeking sponsorship, obtaining grants and organising volunteer groups to undertake practical tasks (Selman, 2004). Arguably, the established routes would benefit from the level of community engagement seen on new, non-designated routes 
like the Isle of Arran Coastalway, which have been developed as a result of the efforts of local people, with practically no external support or funding:

[it has been] very much a volunteer effort, we've done it without funding [and] we're now trying to improve and maintain the route with volunteer efforts. I think that's something that's going to happen more in the future. We've certainly found that in Arran ... in each of the villages, there's an improvement committee which tries to improve its area, and they do it in all sorts of ways. One of the ways is to try and improve access, paths, for the local community, so we've tapped into that. And we've had a number done locally which are part of the course of the Way, but they have been improved by a combination of work that our own volunteers have done and the local community. (Interview with Isle of Arran Coastalway Group, August 2004).

\section{CONCLUSION}

A positive feature of the existing stakeholder approach to the management of LDRs in Scotland is that it emphasises collaboration between various communities of interest, tapping into key partner organisations and individuals. One indication of its success is that the structures in place to manage and develop LDRs are largely those which are to be found in the land reform legislation with its emphasis on things like local and national access forums, community consultation etc. But there remain opportunities to engage with a broader range of communities of interest and to encourage 
participatory and flexible approaches to involvement. Further, as major initiatives like National Parks become established, there is a chance to raise the standards of management and governance of recreational land in Scotland and to exemplify best practice. It is also important that sharing best practice is prioritised. In this regard while there is no likelihood of other LDRs being designated in the foreseeable future, there is no reason why representatives of non-designated routes could not be supported in kind by agencies involved with designated LDRs; for example, involvement with the LDR forum may be a sensible approach to sharing best practice.

Notwithstanding inevitable differences of opinion among stakeholders, again the evidence suggests that the existing funding model for LDRs has worked reasonably well to date. But a more difficult challenge facing those involved with LDRs is how the future development of the routes should be funded.

If we're going to retain the sort of network of paths we've got, both long distance and shorter local ones, then somebody somewhere is going to have to [come up with] some money to go into it and everybody seems to be saying, not me please, at this stage. (Interview with Highlands of Scotland Tourist Board, June 2004)

While national funding of a national resource may be the preferred model, most stakeholders recognise that within the present political climate this is simply unrealistic. Hence there is a need to identify other mechanisms to ensure the continued relevance of LDRs. At one level there is a need to 
promote better understanding of the economic and social benefits arising out of LDRs with a view to persuading local authorities and others to take stronger ownership of them. There is also a requirement to emphasise functional aims that may arise through participatory approaches to stakeholder management. In particular, the active involvement of different communities of interest may allow route managers to use public funds to encourage funds from other sources. These sources include the private sector and it is clear that existing stakeholders and communities of interest need to be more receptive to private sector involvement in LDRs.

\section{ACKNOWLEDEGEMENTS}

I am grateful to representatives of the various bodies who agreed to be interviewed as part of this research and to the editor of Managing Leisure and two anonymous reviewers for their constructive comments on an earlier draft of this paper.

\section{REFERENCES}

Aas, C., Ladkin, A. and Flectcher, J. (2005) Stakeholder collaboration and heritage management, Annals of Tourism Research, 32(1), 28-48.

Ansoff, I. (1965) Corporate Strategy, New York: McGraw Hill.

A' Phairc (2004) Way out west, $A^{\prime}$ Phairc, 3, 20-21.

Borrini-Feyerabend, G. (1999) Collaborative management of protected areas, in S. Stolton and N. Dudley (eds) Partnerships for Protection: New Strategies 
for Planning and Management for Protected Areas, London: Earthscan, 224234.

Burch, W.R. Jnr (1979) The Long Trail as Significant Cultural Creation, in W.R. Burch Jnr (ed) Long Distance Trails: The Appalachian Trail as a Guide to Future Research and Management Needs, New Haven, Yale University, 910.

The Countryside Agency (2003) Future management of national trails (AP03/09). Paper presented at the $34^{\text {th }}$ meeting of the Countryside Agency, John Dower House, Cheltenham, 10 April.

The Countryside Agency (2001) Future management of national trails (AP01/11). Paper presented at the $20^{\text {th }}$ meeting of the Countryside Agency, Belmont House Hotel, Leicester, 10 May.

Covell, D. (2004) Attachment, allegiance and a convergent application of stakeholder theory to Ivy League athletics, International Sports Journal, 8(1), $14-26$.

Cyert, R.M. and March, J.G. (1963) A behavioural theory of the firm, Englewood Cliffs, Prentice Hall.

Donaldson, T. and Preston, L. (1995) The stakeholder theory of the corporation: concepts, implications and evidence, Academy of Management Review, 20(1), 65-91.

Edensor, T. (2000) Walking in the British countryside: reflexivity, embodies practices and ways to escape, Body and Society, 6(3/4), 81-106. Freeman, R. (1984) Strategic Management: A Stakeholder Approach, Boston, Pitman. 
Higgins, P. (2000) The contribution of outdoor recreation and outdoor education to the economy of Scotland: Case studies and preliminary findings, Journal of Adventure Education and Outdoor Learning, 1(1), 69-82 Land Reform (Scotland) Act 2003, Edinburgh: The Stationery Office. Mattingly, A. (2005). Pennine Way and the dawn of long-distance footpaths, Walk, 6, 24-29.

Michaels, S., Mason, R. and Solecki, W. (1999) Motivations for econstewardship partnerships: examples from the Adirondack Park, Land Use Policy, 16, 1-9.

Mikalsen, K.H. and Jentoft, S. (2001) From user groups to stakeholders? The public interest in fisheries management, Marine Policy, 25, 281-292.

Morrow, S. (2003) The People's Game? Football, finance and society, Basingstoke, Palgrave.

Partnership for National Trails (2005) About the partnership for national trails (at www.nationaltrailspartnership.org ).

Ravenscroft, N. (2004) Tales from the tracks, International Review for the Sociology of Sport, 39(1), 27-44.

Reed, M.G. (1997) Power relations and community-based tourism planning, Annals of Tourism Research, 24(3), 566-591.

Rubin, R.A. (ed) (2000) Trail News: A History of the Appalachian Trail Conference, Harpers Ferry, Appalachian Trail Conference.

Scottish Outdoor Access Code (2005) History of the access legislation (at www.outdooraccess-scotland.com ) 
Scholes, K. (2001) Stakeholder mapping: a practical tool for public sector managers, in G. Johnson and K. Scholes (eds) Exploring Public Sector Strategy, Pearson, Harlow, 99-105.

Scottish Parliament Information Centre (1999) Non-domestic rates. Research Note 99/45, Scottish Parliament Information Centre, Edinburgh.

Selman, P. (2004) Community participation in the planning and management of cultural landscapes, Journal of Environmental Planning and Management, 47(3), 365-392.

SNH (2005) SNH Web site: Organisational structure (at www.snh.org.uk). SNH (2004) Natural Heritage Trends. Information Note Series, Edinburgh, Scottish Natural Heritage.

SNH (2003), A Natural Perspective: Scottish Natural Heritage's Corporate Strategy, Edinburgh, Scottish Natural Heritage.

SNH (1998) Jobs and the Natural Heritage: The Natural Heritage in Rural Development, Perth, Scottish Natural Heritage.

SNH (1997), Long Distance Routes in Scotland, SNH Policy Paper, Perth, Scottish Natural Heritage.

Spotlight (2002) No Way ... Yes Way, Spotlight - Ayrshire \& Arran Tourist Monthly, February (at http://spotlight.ayrshire-

arran.com $/$ main.cfm?ID=222\&offset=7 ).

Storer, R. (1991) Exploring Scottish Hill Tracks, London, David \& Charles. Te Araroa (2005) The Trust - a hiking trail the length of New Zealand (at www.teararoa.org.nz/the trust.php ) 
Figure 1: Official long distance routes (LDRs) in Scotland

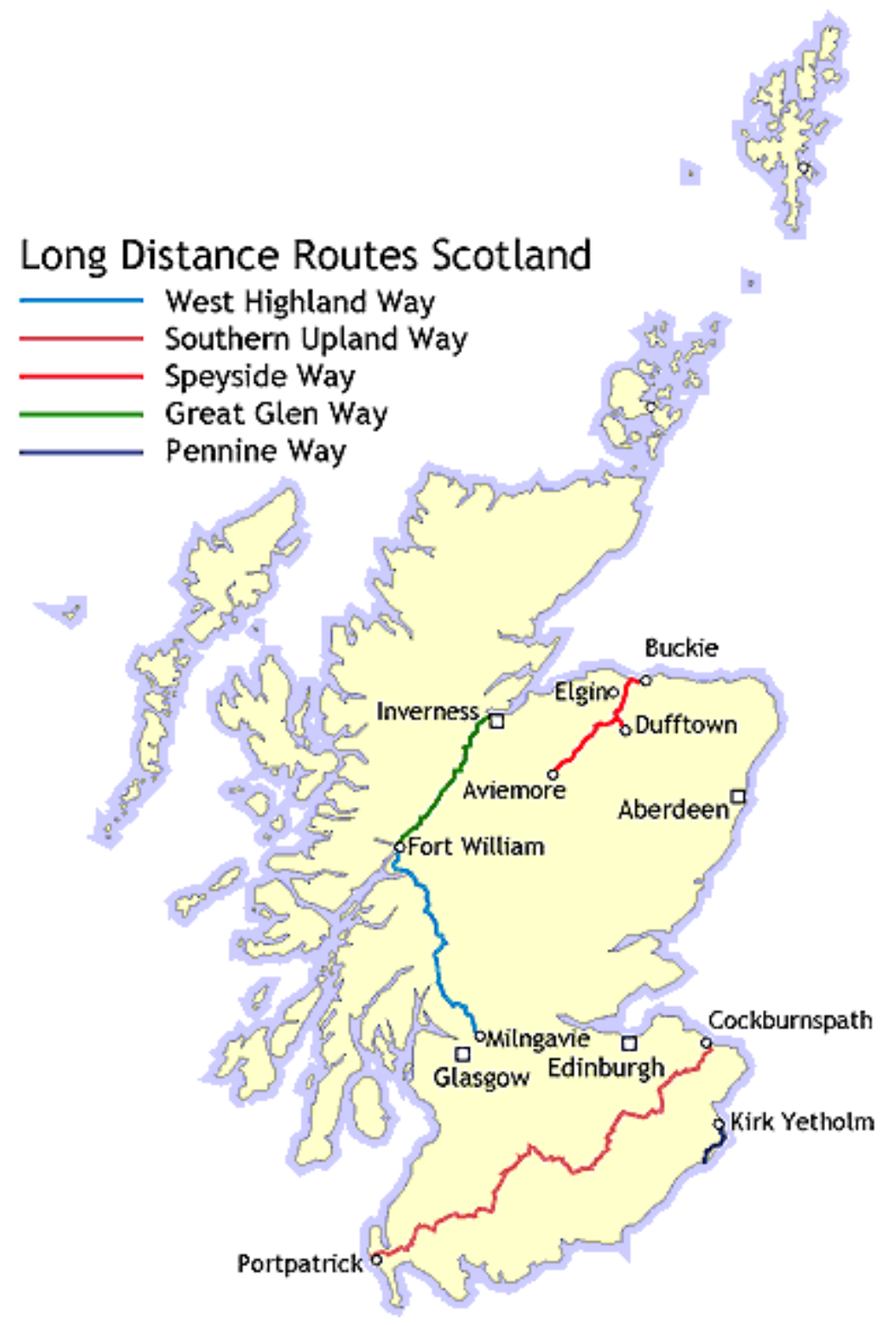

